\title{
Response of Maize (Zea mays L.) Secondary Growth Parameters to Conservation Agriculture and Conventional Tillage Systems in Zimbabwe
}

\author{
Regina Hlatywayo ${ }^{1}$, Blessing Mhlanga ${ }^{1}$, Upenyu Mazarura ${ }^{1}$, Walter Mupangwa ${ }^{2} \&$ Christian $_{\text {Thierfelder }}{ }^{2}$ \\ ${ }^{1}$ Department of Crop Science, Faculty of Agriculture, University of Zimbabwe, Mount Pleasant, Harare, \\ Zimbabwe \\ ${ }^{2}$ International Maize \& Wheat Improvement Centre (CIMMYT), Mount Pleasant, Harare, Zimbabwe \\ Correspondence: Regina Hlatywayo, Department of Crop Science, Faculty of Agriculture, University of \\ Zimbabwe, P.O. Box MP 167, Mount Pleasant, Harare, Zimbabwe. Tel: 263-773-907-272. E-mail: \\ regina.hlatywayo@gmail.com
}

Received: August 4, 2016

doi:10.5539/jas.v8n11p112

\author{
Accepted: September 17, 2016 \\ Online Published: October 15, 2016 \\ URL: http://dx.doi.org/10.5539/jas.v8n11p112
}

\begin{abstract}
Previous, research focused mainly on the effects of conservation agriculture (CA) and conventional practices (CP) on crop yield mostly. A study was conducted at five sites in Zimbabwe from 2012 to 2014 to investigate effects of CA and CP practices on emergence, chlorophyll content, early vigour and grain yield of different maize varieties using 12 hybrids and 4 open pollinated varieties (OPVs). The experiment was laid as a $4 \times 4$ alpha lattice design with three replications. Emergence was higher under CA (75\%) at University of Zimbabwe (UZ) in 2012/13 and Domboshawa Training Centre (DTC) (67\%) compared to CP (71\% and 39\% respectively). Lower early plant vigour was observed under CA compared to CP at most sites. CA had lower leaf chlorophyll content during the early crop growth stages compared to CP. However, at some instances, CA had higher leaf chlorophyll content (45 units) than CP (35 units) at 78 days after sowing in Zimuto 2012/13. For maize yield, CA outperformed CP on a sandy loamy soil (3050 kg ha ${ }^{-1}$ vs $\left.2656 \mathrm{~kg} \mathrm{ha}^{-1}\right)$ and clay soil (4937 kg ha ${ }^{-1} \mathrm{vs} 4274 \mathrm{~kg}$ $\left.\mathrm{ha}^{-1}\right)$. However, on a sandy soil, CP outperformed CA (1764 vs $\left.1313 \mathrm{~kg} \mathrm{ha}^{-1}\right)$. Our results suggest that tillage effects on early maize plant vigor, leaf chlorophyll content and the final yield can be site and season specific. Furthermore, a delay of nutrient release for plant uptake under CA systems was found and potentially implies investigations of new fertilization strategies for such cropping systems.
\end{abstract}

Keywords: chlorophyll, cropping systems, early vigour, grain yield, nitrogen content

\section{Introduction}

Agriculture systems based on tillage and removal/or burning of crop residues pose a threat to food security through accelerated soil degradation (Thierfelder, Mutenje, Mujeyi, \& Mupangwa, 2014). Maize yields are reportedly declining to the highest average yield levels of 1.1 tons ha ${ }^{-1}$ in the past decade (Thierfelder \& Wall, 2009). The need to implement more sustainable ways of farming in the smallholder sector is therefore increasingly important. Several ways present potential solutions in addressing food insecurity and soil degradation, and this range from new and adapted maize varieties to good agronomic practices (Cairns, Sanchez, Vargas, Ordoñez, \& Araus, 2012). Conservation agriculture (CA), based on minimum soil disturbance, permanent soil organic cover, and the use of diverse crop rotations/associations, has the potential for addressing the current food insecurity and soil degradation on smallholder farming systems (Thierfelder et al., 2014). Compared with conventional plough- or hoe-based cultivation practices (CP), CA practices have been shown to increase and stabilize maize yields in studies conducted in different parts of the world (Govaerts, 2009; Thierfelder et al., 2014; Mhlanga, Cheesman, Maasdorp, Mupangwa, \& Thierfelder, 2015). This increase in crop yields under CA could be attributed to increased soil moisture induced by residue retention, increased faunal abundance achieved by reduced disturbance of the soil and residue retention, and increased nitrogen $(\mathrm{N})$ fixation from crop rotations with legumes (Mhlanga et al., 2015; Mutema, Mafongoya, Nyagumbo, \& Chikukura, 2013; Thierfelder \& Wall, 2009). However, the smallholder farmers still regard CP as an easier farming method based on how easily weeds are controlled at the beginning of the season through ploughing which buries the weeds 
(Derksen, Lafond, Thomas, Loeppky, \& Swanton, 1993). Furthermore, CP improves soil aeration but this benefit is outweighed by the detrimental effects it has on the environment, leading to yield decreases in the longer term (Reicosky, Sauer, \& Hatfield, 2011). Moreover, CA in some instances reduces yield through waterlogging, reduced soil temperatures and N lockup (Chikowo, Mapfumo, Nyamugafata, Nyamadzawo, \& Giller, 2003).

The growth and development of maize is affected by management practices such as soil fertility and weed management. Differences in crop performance are likely to occur between CA and CP as they involve different management strategies. Altuntas and Dede (2009) observed an increased maize crop emergence under CA compared to CP. On the contrary, Hayhoe, Dwyer, Stewart, White, and Culley (1996) found a slow and uneven maize crop emergence under CA compared to $\mathrm{CP}$ and this was directly linked to low temperatures under CA systems which are generally triggered by residue retention. Burgess, Mehuys, and Madramootoo (1996) pointed out possible effects of allelopathy of the maize residues usually retained under CA systems to the emerging maize seed. Cairns et al. (2012) investigated in-vivo chlorophyll content in maize and found a strong and positive relationship between leaf chlorophyll content and grain yield. The relationship between the two parameters was stronger especially towards and during maize flowering in the same study. However, because of different soil conditions under CA compared to $\mathrm{CP}$ i.e. the temporal unavailability of $\mathrm{N}$ through immobilization in maize stover mulched soils, photosynthesis levels are affected especially during the early stages of crop growth (Verhulst et al., 2011a). The temporal unavailability of $\mathrm{N}$ is caused by the increased levels of immobilization which is triggered by the high $\mathrm{C}$ : $\mathrm{N}$ ratio of mulching material such as maize stover (Wortman, 2006). Furthermore, the temporal unavailability of $\mathrm{N}$ has an effect on early vigour of the maize crop as growth and vigour are dependent on photosynthesis (Lundy, Pittelkow, Linquist, Liang, Van Groenigen, Lee, \& Van Kessel, 2015). Low soil temperatures under CA systems affect germination, vigour and growth of crops (Duiker \& Haldeman, 2006). In a study carried out by Verhulst et al. (2011b), the initial maize growth was slower under CA compared with $\mathrm{CP}$ although this did not translate into significant yield differences at harvest. The slower initial maize growth under $\mathrm{CA}$ may be due to the slower mineralization of $\mathrm{N}$ into the soil that could be delayed by up to three weeks (Chikowo et al., 2003).

On the other hand, soil tillage increases mineralization of soil organic matter (SOM) because the soil environment becomes well aerated (Barbera, Poma, Gristina, Novara, \& Egli, 2012). However, increased mineralization leads into high potential loss of carbon $(\mathrm{C})$ and nitrogen $(\mathrm{N})$ from the soil through erosion, leaching and mining by plants (Barbera et al., 2012). As a result, maize under CP can have increased access to soil nutrients leading to high early plant vigour and a higher rate of growth compared with maize under CA (Chikowo et al., 2010). This creates differences in growth of plants under CA and CP cropping systems. Information on effects of tillage systems on secondary growth parameters in maize is still limited. The aim of this study was to investigate the effects of different management systems (i.e. CA and CP) on maize secondary traits such as early vigour, leaf chlorophyll content, and grain yield. The hypothesis of the study was that different management systems affect growth and yield of maize (on above mentioned parameters). This was tested on a set of locally produced maize varieties under different environments in Zimbabwe.

\section{Materials and Methods}

\subsection{Study Description}

The experiment was established in the 2009-10 season with maize varieties evaluated under CA tillage system only. For comparison of tillage systems, CP tillage system was introduced in 2011-12 with maize varieties grown in both systems. This current study however, presents data from the 2012-13 and 2013-14 cropping seasons. The study was carried out at five experimental locations: University of Zimbabwe (UZ) $\left(17.73^{\circ} \mathrm{S} ; 31.04^{\circ} \mathrm{E}\right.$ and 1483 meters above sea level (m.a.s.l), Domboshawa Training Centre (DTC) $\left(17.62^{\circ} \mathrm{S} ; 31.17^{\circ} \mathrm{E}\right.$ and $1500 \mathrm{~m}$.a.s.l), Madziva $\left(17.00^{\circ} \mathrm{S} ; 31.43^{\circ} \mathrm{E}\right.$ and 1169 m.a.s.l), Hereford $\left(17.42^{\circ} \mathrm{S} ; 31.44^{\circ} \mathrm{E}\right.$ and 1054 m.a.s.l), and Zimuto $\left(19.85^{\circ} \mathrm{S} ; 30.88^{\circ} \mathrm{E}\right.$ and 1223 m.a.s.l). The soils at $\mathrm{UZ}$ are characterized by a high clay content of more than $40 \%$ and are classified as Chromic luvisols (Nyamapfene, 1991). Domboshawa Training Centre has soils classified as Gleyic luvisols and has a 5\% clay content generated from granitic parent material (Thierfelder \& Wall, 2009). Hereford soils are heavy red clays with up to $40 \%$ clay content and classified as Chromic luvisols (Nyamapfene, 1991). Madziva is characterized by sandy soils which are classified as Gleyic luvisols generated from granite parent material (Thierfelder et al., 2012). Dominant soils at Zimuto are Arenosols generated from granitic sands of low inherent fertility and less than 5\% clay content (Thierfelder \& Wall, 2012).

\subsection{Maize Varieties}

Twelve commonly grown maize hybrids and four open pollinated varieties (OPVs) from different sources were used in this study. The choice of maize genotypes was based on commercial availability in Zimbabwe and wide 
adoption in southern Africa (Kassie et al., 2012). The genotypes can be subdivided into early maturing (i.e. SC403, PAN 413, PHB 3253 and PHB P2859W), medium maturing (i.e. PAN 53, Pristine 1, SC 513, SC 533, SC 635, ZAP 51, ZAP 61, ZS 261, PGS 63) and late maturing (i.e. SC 637) hybrids; and early maturing (i.e. ZM 401 and ZM 309) and medium maturing (i.e. ZM 523 and ZM 525) OPVs.

\subsection{Experimental Design}

The experiment was set as an alpha lattice design at all sites with the CA and CP plots laid adjacent to each other, replicated three times and blocked four times against slope. At all sites, gross plot size measured $4.8 \mathrm{~m} \times 3.6 \mathrm{~m}$ (i.e. $17.28 \mathrm{~m}^{2}$ ) with a net plot size of $3.8 \mathrm{~m} \times 1.8 \mathrm{~m}\left(\right.$ i.e. $\left.6.84 \mathrm{~m}^{2}\right)$.

\subsection{Agronomic Management}

Residues (maize stover) were uniformly spread over the CA plots at a rate of $3 \mathrm{t} \mathrm{ha}^{-1}$ while residues were removed in the $\mathrm{CP}$ plots before disc ploughing to a depth of $25 \mathrm{~cm}$ prior to the beginning of the season. Maize varieties under CA were planted in rip lines created by a Magoye ripper (a ripper tine attached to an ox-drawn mouldboard plough) at all sites except for UZ were basins were created with hand hoes during the dry winter period. Basins under CA were only used at UZ due to the unavailability of animal draft power. Under the practice of CP, planting was done using basins at all sites. Maize was planted at $90 \mathrm{~cm}$ between lines and $50 \mathrm{~cm}$ between plants with 3 seeds per station thinned to 2 to achieve a population of 44, 444 plants ha ${ }^{-1}$ at all sites. Maize plants in both CA and CP received basal fertilizer [Compound D $\left(7 \mathrm{~N}: 14 \mathrm{P}_{2} \mathrm{O}_{5}: 7 \mathrm{~K}_{2} \mathrm{O}\right)$ ] at the rate of $14 \mathrm{~kg}$ $\mathrm{N} \mathrm{ha}^{-1}, 12.2 \mathrm{~kg} \mathrm{P} \mathrm{ha}^{-1}$, and $11.6 \mathrm{~kg} \mathrm{~K} \mathrm{ha}^{-1}$ at sowing.Top dressing was applied to both $\mathrm{CA}$ and $\mathrm{CP}$ in two splits, at four and seven weeks after crop emergence to a total of $69 \mathrm{~kg} \mathrm{~N} \mathrm{ha}^{-1}$ in the form of ammonium nitrate $(34.5 \% \mathrm{~N})$ Weeds were controlled by spraying a tank-mixture of glyphosate [ $N$-(phosphono-methyl)glycine], atrazine [1-Chloro-3-ethylamino-5-isopropylamino-2,4,6-triazine] and metolachlor [(RS)-2-Chloro-N-(2-ethyl-6-methylphenyl)- $N$-(1-methoxypropan-2-l)acetamide] at a rates of $2.51 \mathrm{ha}^{-1}, 3.51 \mathrm{ha}^{-1}$ and $1.01 \mathrm{ha}^{-1}$ active ingredient (ai), respectively, immediately after sowing the seed in the CA plots. In CP plots, weeds were controlled through tillage at the beginning of the season. This was mainly to control grasses and broadleaved weeds. In both CA and CP plots, manual weeding was conducted after crop emergence during the growing period each time weeds reached approximately $10 \mathrm{~cm}$ in height or radius for weeds with a stoloniferous growth habit. Maize stalk borer (Busseola fusca L.) was controlled using Dipterex at a rate of $1.6 \mathrm{~kg}$ ai ha ${ }^{-1}$ applied in granular form into the maize funnel at early signs of attack.

\subsection{Measurements}

\subsubsection{Rainfall}

Rainfall was measured at each site using a standard rain gauge located in an open space next to the experimental location. Readings were taken in the morning after each rainfall event.

\subsubsection{Soil Sampling and Chemical Analysis}

Soil sampling for fertility analyses was done at each experimental location using the stratified random sampling method in each replicate of each cropping system. Three samples were taken from each replicate using a soil auger at three soil depth levels i.e. $0-10 \mathrm{~cm}, 10-30 \mathrm{~cm}$ and $30-90 \mathrm{~cm}$. A composite sample was then created representing each depth and each cropping system. Soil samples were submitted to the Soil Chemistry and Soils Institute of the Department of Research and Specialist Services of Zimbabwe (DR \& SS) to analyze for chemical and physical properties of the soils.

\subsubsection{Maize Crop Emergence}

Days to $50 \%$ emergence were determined by counting the number of seedlings emerging in the two central rows of each plot daily for 10 days. Emergence percentage was recorded as the number of plants which emerged out of plants which were expected to emerge (60 plants) within the two central rows.

\subsubsection{Maize Plant Height, Leaves per Plant and Dry Matter (Early Vigour)}

At 6 weeks after sowing, 5 plants were selected from each plot and height measured from the root crown to the top of the innermost leaf. The number of leaves (omitting the bottom dry leaves) per plant were counted from the same sample and the average number of leaves calculated. To determine the above ground biomass, a destructive sampling method from the border rows was done and 5 plants were selected randomly, oven dried to a constant weight at $65^{\circ} \mathrm{C}$ for 72 hours and the dry weight recorded. 


\subsubsection{Leaf Chlorophyll Content}

In vivo chlorophyll content of leaves was estimated using a portable chlorophyll meter (SPAD-502 ${ }^{\circledR}$, Minolta, Tokyo, Japan). Measurements were taken weekly starting from 6 weeks after sowing on the upper most extended leaf on 5 randomly selected plants per plot. However, prior to flowering (i.e. about 9 weeks after sowing) onwards, the ear leaf was used instead as the sampling leaf reached senescence stage as this had the greatest contribution of assimilates to the sink (ear).

\subsubsection{Yield Measurements}

Grain and stover were harvested for yield determination from the net plot measuring 2 rows by $4.8 \mathrm{~m}$. The number of plants and cobs per net plot were recorded. The fresh cobs and stover were weighed and their weight recorded. A sub-sample comprising five cobs was extracted from each plot and the fresh weight of cobs recorded. A stover sub-sample of approximately $500 \mathrm{~g}$ was taken and its fresh weight measured. The stover and cob sub-samples were dried in an oven and the dry weight recorded. The grain weight was determined after shelling for each plot. Grain moisture was determined using a Dickey-john mini GAC® moisture tester and yield was expressed at $12.5 \%$ moisture content.

\subsection{Data Analysis}

Data were subjected to analysis of variance (ANOVA), generalized linear models, and multiple linear regressions. This was done to identify significant effects of tillage systems on emergence, early vigour and leaf chlorophyll and the contribution of the primary traits to grain yield using GenStat version 12 (VSN International, 2002) statistical packages. Where the effects of tillage systems were significantly different, separation was done using the Tukey's test (HSD) at $\mathrm{P}<0.05$ probability level.

\section{Results}

\subsection{Rainfall Data across Sites and Seasons}

In the 2012-13 season, all sites received above $600 \mathrm{~mm}$ of rainfall and had an effective growing season of about 80 days except for Zimuto which had rainfall below $400 \mathrm{~mm}$ and an effective growing period of 60 days (Figure 1). There was a short dry spell of about 15 days at Zimuto immediately after planting and a sharp increase in rainfall immediately after planting at DTC and Hereford of about $100 \mathrm{~mm}$ in 10 days. In the 2013-14 season, there was a longer growing period of over 80 days compared with the 2012-13 season. However, Zimuto and UZ sites experienced a short dry spell of 10 days after planting in 2013-14 season (Figure 1).
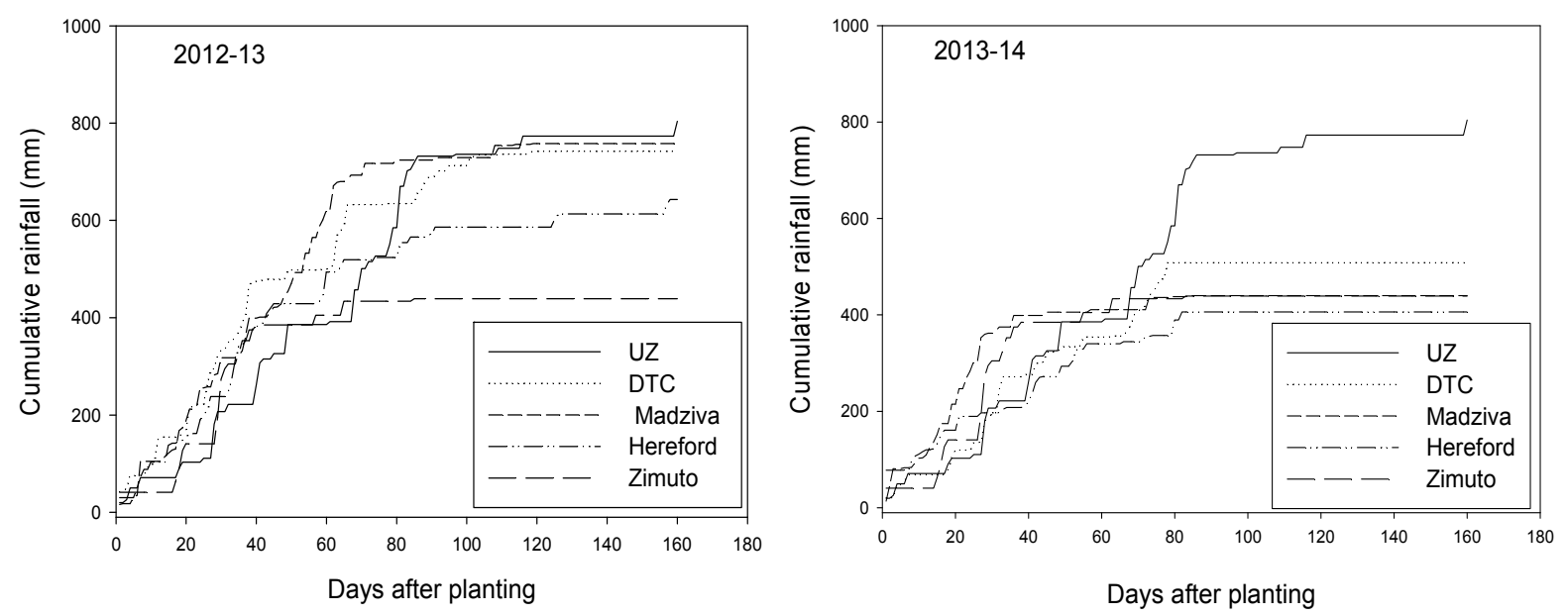

Figure 1. Rainfall patterns at UZ (University of Zimbabwe), DTC (Domboshawa Training Centre), Madziva, Hereford and Zimuto in the 2012-13 and 2013-14 seasons

\subsection{Soil Chemical and Physical Properties at the Five Experimental Sites}

Soil chemical and physical properties were different at the five study sites (Table 1). Hereford and UZ sites had higher clay content $(<40 \%)$ while Madziva and Zimuto had soils with a sandy texture $(<14 \%$ clay $)$. Generally the light textured soils had less amounts of phosphorus $(\mathrm{P})(<18 \mathrm{mg} / 100 \mathrm{~g})$ and potassium $(\mathrm{K})(<0.013 \mathrm{mg} / 100$ 
g) and were acidic $(<5.9)$ compared to the heavy textured soils. Heavy textured soils had a pH range of 6-7. Madziva had soil with the lowest clay content $(8 \%$ in the top layer) and was the most acidic $(\mathrm{pH}<6)$. The highest total $\mathrm{N}$ levels $(>50 \mathrm{ppm})$ were recorded in the heavy textured soils compared with levels $(<34 \mathrm{ppm})$ in light textured soils. Higher levels of available N under CA compared with CP were found at Domboshawa, Hereford and UZ whilst CP soils had a higher available N content at Zimuto and Madziva. Furthermore, Zimuto and Madziva had more acidic soils under CA compared with CP. However, at the other sites, $\mathrm{pH}$ was similar in both cropping systems (Table 1).

Table 1. Soil properties at five experimental sites at UZ farm (University of Zimbabwe), DTC (Domboshawa Training Centre), Madziva, Hereford and Zimuto on the onset of 2012-13 season

\begin{tabular}{|c|c|c|c|c|c|c|c|c|c|c|c|}
\hline \multirow[b]{2}{*}{ Location } & \multirow[b]{2}{*}{ Depth $(\mathrm{cm})$} & \multicolumn{5}{|c|}{$\mathrm{CA}$} & \multicolumn{5}{|c|}{$\mathrm{CP}$} \\
\hline & & $\begin{array}{l}\text { Clay } \\
(\%)\end{array}$ & $\begin{array}{l}\text { Available N } \\
\text { (ppm) }\end{array}$ & $\begin{array}{l}\text { Total N } \\
(\mathrm{ppm})\end{array}$ & $\begin{array}{l}P \\
(\mathrm{mg} / 100 \mathrm{~g})\end{array}$ & $\mathrm{pH}$ & $\begin{array}{l}\text { Clay } \\
(\%)\end{array}$ & $\begin{array}{l}\text { Available N } \\
\text { (ppm) }\end{array}$ & $\begin{array}{l}\text { Total N } \\
\text { (ppm) }\end{array}$ & $\begin{array}{l}P \\
(\mathrm{mg} / 100 \mathrm{~g})\end{array}$ & $\mathrm{pH}$ \\
\hline \multirow[t]{3}{*}{$\mathrm{UZ}$} & $0-30$ & 50 & 35 & 80 & 16 & 6.1 & 48 & 30 & 63 & 29 & 6.1 \\
\hline & $30-60$ & 60 & 27 & 50 & 4 & 6.4 & 52 & 21 & 44 & 12 & 6.2 \\
\hline & $60-90$ & 41 & 76 & 104 & 5 & 6.5 & 42 & 26 & 45 & 10 & 6.3 \\
\hline \multirow[t]{3}{*}{ DTC } & $0-30$ & 23 & 34 & 43 & 28 & 5.1 & 24 & 19 & 28 & 9 & 5 \\
\hline & $30-60$ & 37 & 28 & 27 & 5 & 5.8 & 30 & 10 & 15 & 5 & 6.2 \\
\hline & $60-90$ & 31 & 27 & 43 & 7 & 6.2 & 34 & 16 & 36 & 3 & 5.9 \\
\hline \multirow[t]{3}{*}{ Madziva } & $0-30$ & 8 & 16 & 31 & 12 & 5.3 & 5 & 22 & 30 & 10 & 5.3 \\
\hline & $30-60$ & 8 & 1 & 9 & 3 & 5.2 & 6 & 10 & 11 & 3 & 5.3 \\
\hline & $60-90$ & 13 & 22 & 31 & 7 & 5.9 & 9 & 14 & 22 & 6 & 5.6 \\
\hline \multirow[t]{3}{*}{ Hereford } & $0-30$ & 46 & 16 & 66 & 11 & 6 & 48 & 7 & 52 & 6 & 6.1 \\
\hline & $30-60$ & 47 & 12 & 21 & 1 & 6.3 & 51 & 10 & 16 & 5 & 6.3 \\
\hline & $60-90$ & 53 & 7 & 12 & 1 & 6.4 & 53 & 11 & 15 & 11 & 6.5 \\
\hline \multirow[t]{3}{*}{ Zimuto } & $0-30$ & 14 & 21 & 34 & 18 & 5.9 & 11 & 1 & 27 & 4 & 5.2 \\
\hline & $30-60$ & 14 & 16 & 22 & 1 & 5.1 & 12 & 2 & 10 & 1 & 5.1 \\
\hline & $60-90$ & 13 & 5 & 13 & 2 & 5.7 & 15 & 1 & 10 & 4 & 5.7 \\
\hline
\end{tabular}

\subsection{Emergence under $C A$ and $C P$}

In 2012-13 season, emergence was significantly $(\mathrm{P}<0.05)$ higher under $\mathrm{CA}$ at UZ $(75 \%)$ compared to $\mathrm{CP}(71 \%)$. Emergence was significantly higher in CP (63\%) at Zimuto in the same year compared with CA (43\%) (Figure 2). In the 2013-14 season, CA $(67 \%)$ had significantly $(\mathrm{P}<0.05)$ higher emergence than CP $(39 \%)$ at DTC. Conventional practice had significantly $(\mathrm{P}<0.05)$ higher emergence at UZ $(63 \%)$ and Zimuto $(80 \%)$ compared with CA (58\% and 62\% respectively) (Figure 2). High emergence percentage showed a positive relationship with grain yield i.e. one unit increase in emergence resulted in 0.19 units increase in grain yield under CA and 0.007 units under CP (Table 2). Grain yield decreased by 0.03 and 0.04 units for every one unit increase in days to $50 \%$ emergence under CA and CP respectively (Table 2). The multiple linear regression accounted for over 50\% variation on the measured parameters both under CA and CP systems. 

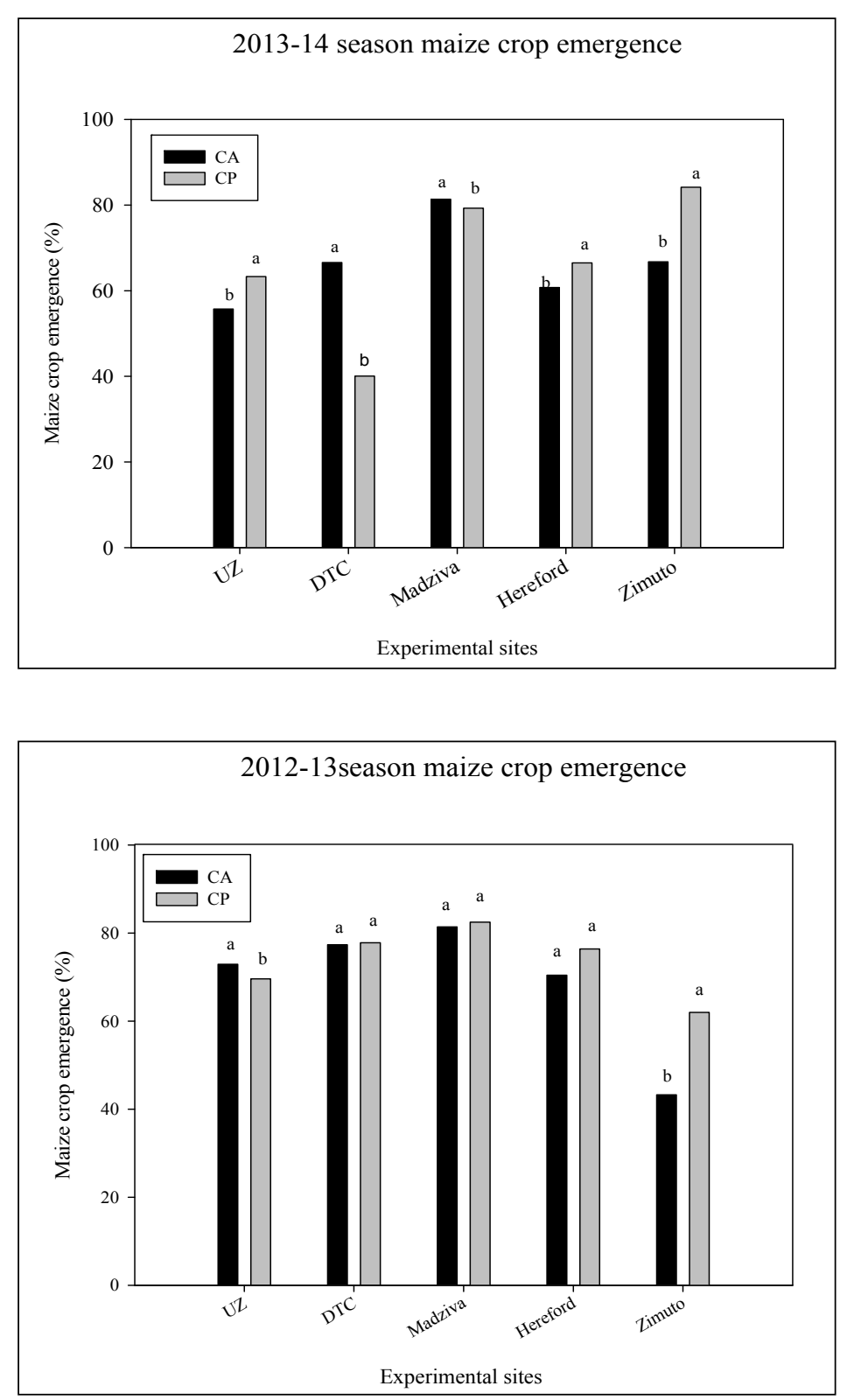

Figure 2. Maize plant emergence percentage under conservation (CA) and conventional practices (CP) at UZ (University of Zimbabwe), DTC (Domboshawa Training Centre), Madziva, Hereford and Zimuto in 2012-13 season 
Table 2. The effect of emergence and early vigour parameters, dry matter, crop height, number of leaves and leaf chlorophyll at 6 weeks after sowing (6 WAS on grain yield under CA (conservation agriculture)

\begin{tabular}{|c|c|c|c|c|}
\hline & \multicolumn{2}{|c|}{$\mathrm{CA}$} & \multicolumn{2}{|c|}{$\mathrm{CP}$} \\
\hline & Estimate & Probability & Estimate & Probability \\
\hline Constant $(\mu)$ & $2.06 \pm 0.59$ & $\mathrm{P}<.001$ & $1.074 \pm 0.354$ & ns \\
\hline Emergence (\%) & $0.019 \pm 0.003$ & ns & $0.007 \pm 0.0027$ & $\mathrm{P}=0.02$ \\
\hline Days to $50 \%$ emergence & $-0.03 \pm 0.008$ & ns & $0.044 \pm 0.01$ & $\mathrm{P}<.001$ \\
\hline Dry matter (g/5 plants) (6 WAS) & $-0.005 \pm 0.001$ & $\mathrm{P}<.001$ & $-0.008 \pm 0.002$ & $\mathrm{P}=0.004$ \\
\hline Crop height $(\mathrm{cm})$ (6 WAS) & $0.008 \pm 0.003$ & ns & $0.03 \pm 0.004$ & $\mathrm{P}<.001$ \\
\hline Number of leaves (6 WAS) & $0.4 \pm 0.02$ & $\mathrm{P}<.001$ & $0.15 \pm 0.03$ & $\mathrm{P}<.001$ \\
\hline Leaf chlorophyll SPAD units (6 WAS) & $0.004 \pm 0.002 \mathrm{a}$ & $\mathrm{P}<.001$ & $0.0006 \pm 0.002$ & ns \\
\hline Coefficient of determination & 0.516 & & 0.55 & \\
\hline se & 1.02 & & 1.04 & \\
\hline
\end{tabular}

\subsection{Early Vigour under $C A$ and $C P$}

In the 2012-13 season, $\mathrm{CA}$ and $\mathrm{CP}$ had significantly $(\mathrm{P}<0.05)$ different total dry matter weight of the maize plants at all sites. Furthermore, the number of leaves per plant at all sites except Hereford, and plant height at DTC and Hereford, were significantly $(\mathrm{P}<0.05)$ different (Table 3). At four of the five sites (DTC, Madziva, Zimuto and Hereford), $\mathrm{CP}$ had a significantly $(\mathrm{P}<0.05)$ higher dry matter compared with CA in $2012-13$ season. It was only at UZ where CA outperformed the CP treatment. There was no clear trend of CA and CP effects on plant height at most sites. Significant differences in height were only observed at DTC and Hereford where CP out-performed CA (Table 3). During the 2013-14 season all sites had significantly $(\mathrm{P}<0.05)$ more dry mass under CP compared with CA except at Hereford. More leaves were found in the CP system at UZ, DTC, and Zimuto whereas CA outperformed CP at DTC only. A generally lower total dry matter weight was observed at the sandy soil sites, Madziva (9-39 g/5 plants) and Zimuto ( $<36 \mathrm{~g} / 5$ plants $)$ compared with the clay soil sites.

Table 3. Early vigour (E.V) parameters, dry matter, leaves per plant and plant height at UZ farm (University of Zimbabwe), DTC (Domboshawa Training Centre), Madziva, Hereford and Zimuto under CA (Conservation Agriculture) and CP (Conventional Practices) in 2012-13 and 2013-14 seasons at 6 weeks after crop sowing

\begin{tabular}{|c|c|c|c|c|c|c|c|c|c|c|}
\hline & & \multicolumn{9}{|c|}{ Early vigour parameter } \\
\hline & & \multicolumn{3}{|c|}{ Total dry matter weight (g) } & \multicolumn{3}{|c|}{ Average leaves per plant } & \multicolumn{3}{|c|}{ Average plant height $(\mathrm{cm})$} \\
\hline & & $\mathrm{CA}$ & $\mathrm{CP}$ & $\mathrm{P}$ value & $\mathrm{CA}$ & $\mathrm{CP}$ & $\mathrm{P}$ value & $\mathrm{CA}$ & $\mathrm{CP}$ & $\mathrm{P}$ value \\
\hline \multirow[t]{5}{*}{$2012-13$} & UZ & $80^{\mathrm{a}}$ & $55^{\mathrm{b}}$ & 0.003 & $6^{\mathrm{b}}$ & $7^{\mathrm{a}}$ & 0.001 & 57 & 47 & NS \\
\hline & DTC & $21.2^{\mathrm{b}}$ & $48^{\mathrm{a}}$ & 0.001 & $7^{\mathrm{b}}$ & $8^{\mathrm{a}}$ & 0.03 & $35^{\mathrm{b}}$ & $44^{\mathrm{a}}$ & 0.004 \\
\hline & Madziva & $10^{\mathrm{b}}$ & $31^{\mathrm{a}}$ & 0.002 & $6^{\mathrm{b}}$ & $7^{\mathrm{a}}$ & 0.002 & 40 & 40 & NS \\
\hline & Hereford & $100^{\mathrm{b}}$ & $207^{\mathrm{a}}$ & 0.002 & 9 & 9 & NS & $108^{\mathrm{b}}$ & $126^{\mathrm{a}}$ & 0.001 \\
\hline & Zimuto & $22^{\mathrm{b}}$ & $30^{\mathrm{a}}$ & 0.001 & $5^{\mathrm{b}}$ & $6^{\mathrm{a}}$ & 0.003 & 21 & 22 & NS \\
\hline \multirow[t]{5}{*}{$2013-14$} & UZ & $66^{\mathrm{b}^{-}}$ & $76^{a}$ & 0.003 & $8^{\mathrm{b}}$ & $9^{a}$ & 0.001 & 71 & 77 & $\mathrm{NS}$ \\
\hline & DTC & 42.52 & 50 & NS & $9^{\mathrm{a}}$ & $8^{\mathrm{b}}$ & 0.03 & 48 & 45 & NS \\
\hline & Madziva & $9^{b}$ & $39^{\mathrm{a}}$ & 0.002 & $4^{\mathrm{b}}$ & $5^{\mathrm{a}}$ & 0.002 & 27 & 27 & NS \\
\hline & Hereford & $250^{\mathrm{a}}$ & $108^{\mathrm{b}}$ & 0.001 & 8 & 8 & NS & 82 & 82 & NS \\
\hline & Zimuto & $25^{\mathrm{b}}$ & $35^{\mathrm{a}}$ & 0.001 & $8^{\mathrm{b}}$ & $9^{a}$ & 0.003 & $35^{\mathrm{b}}$ & $50^{\mathrm{a}}$ & 0.001 \\
\hline
\end{tabular}

Note. Means followed by different letters within the same row are significantly different from each other at $\mathrm{P}<$ 0.05 probability level.

\subsection{Leaf Chlorophyll Content in CA and CP Systems}

Maize leaf chlorophyll content consistently fluctuated in both cropping systems throughout the seasons (Figures 3 and 4). There was a significant $(\mathrm{P}<0.05)$ difference between $\mathrm{CA}$ and $\mathrm{CP}$ systems which was more pronounced in 2012-13 season compared with 2013-14. In the CA system, chlorophyll content was lower compared with CP at initial growth stages of maize at Hereford in the 2012-13 season and at Zimuto in both seasons (Figures 3 and 
4). At Zimuto, greater chlorophyll content was observed in CA treatments (43 units) compared with CP plots (37 units) towards the end of the season (Figure 3). In 2013-14 season, no differences $(\mathrm{P}>0.05)$ in chlorophyll content were observed at all sites except for Zimuto (Figure 4).
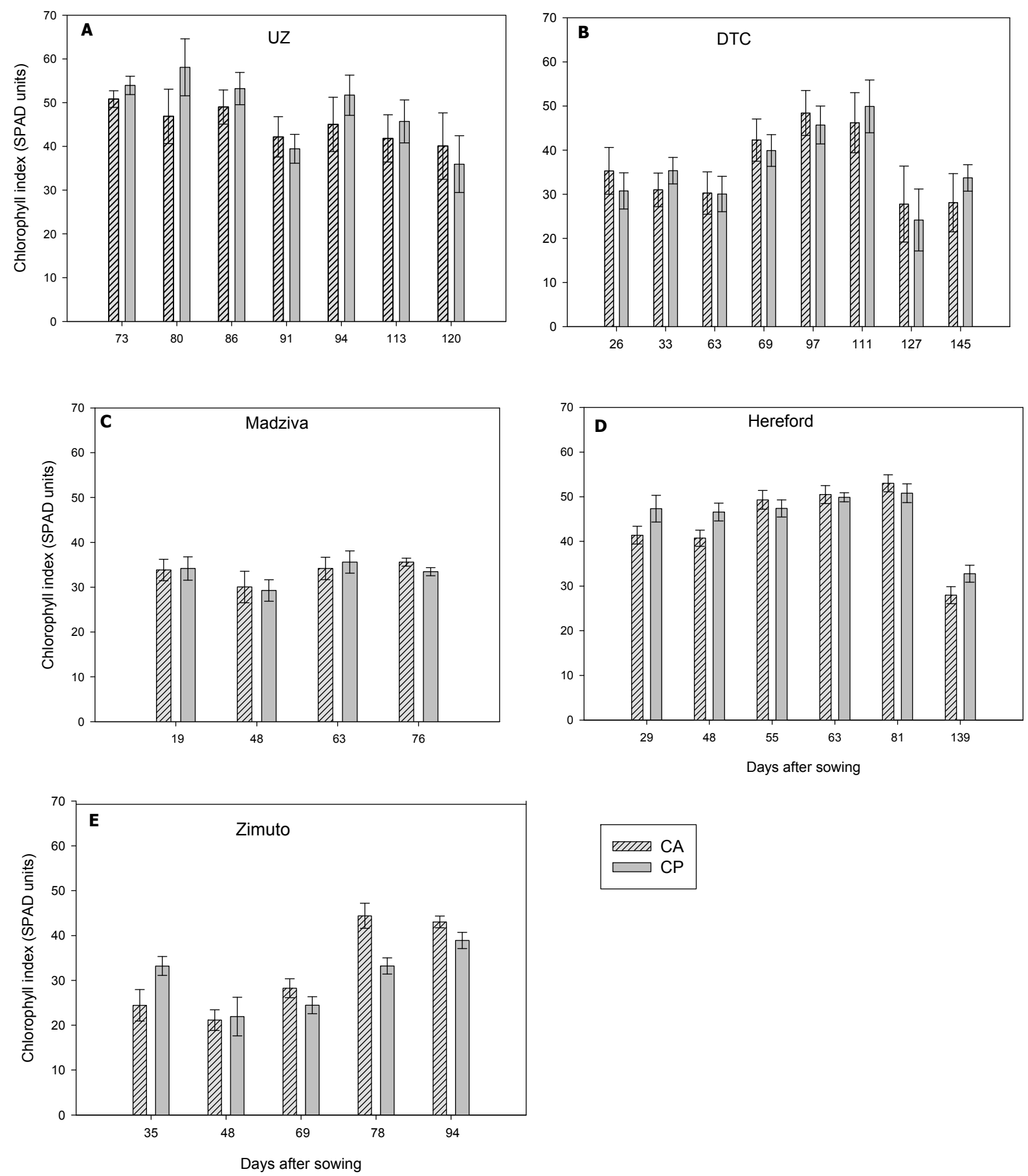

Figure 3. Leaf chlorophyll content at UZ (University of Zimbabwe), DTC (Domboshawa training centre), Madziva, Hereford and Zimuto under CA (conservation agriculture) and CP (conventional practices) in 2012-13 season 

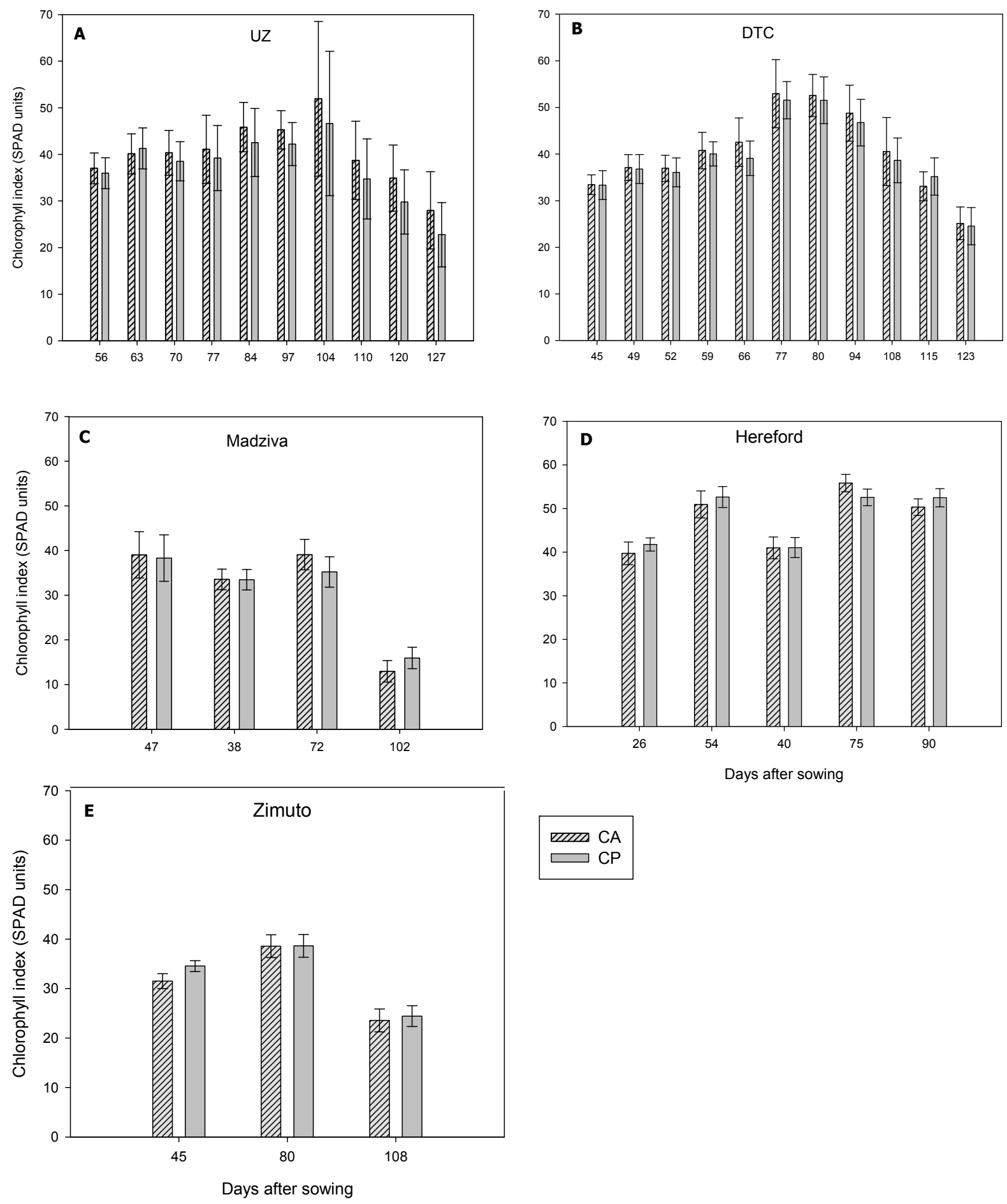

Figure 4. SPAD units (leaf chlorophyll estimates) at UZ (University of Zimbabwe), DTC (Domboshawa Training centre), Madziva, Hereford and Zimuto under conservation agriculture (CA) and conventional practices $(\mathrm{CP})$ in the 2013-14 season

\subsection{Grain Yield under CA and CP and Its Relationship with Early Vigour and Chlorophyll Trends}

Tillage systems significantly $(\mathrm{P}<0.05)$ affected grain yield at Madziva and DTC in the 2012-13 season and, DTC and Hereford in the 2013-14 season (Table 4). At Madziva CP and CA had a maize yield of 1764 and 1313 $\mathrm{kg} \mathrm{ha}^{-1}$, respectively (Table 4). DTC site had $3050 \mathrm{~kg} \mathrm{ha}^{-1}$ in CA and $2656 \mathrm{~kg} \mathrm{ha}^{-1}$ in CP in the same season. Hereford site had $4937 \mathrm{~kg} \mathrm{ha}^{-1}$ in CA and $4274 \mathrm{~kg} \mathrm{ha}^{-1}$ in CP. Seasons, sites, and varieties showed significant (P 
$<0.05$ ) difference (Table 5). Greater yields were attained in the 2013-14 season compared with the 2012-13 season. Hereford had significantly $(\mathrm{P}<0.05)$ higher grain yield of $5813 \mathrm{~kg} \mathrm{ha}^{-1}$ compared with the rest of the sites with Madziva having lowest yield of $1822 \mathrm{~kg} \mathrm{ha}^{-1}$. All the sites had a higher grain yield in 2013-14 season compared to 2012-13 season except for Madziva. There was no significant genotype $\times$ cropping system interaction and varietal performance between the two tillage systems observed (Table 5).

Table 4. Conservation agriculture (CA) and conventional practice (CP) effects on grain yield $\left(\mathrm{kg} \mathrm{ha}^{-1}\right)$ of different varieties at UZ (University of Zimbabwe), DTC (Domboshawa Training centre), Madziva, Hereford (H/ford) and Zimuto in 2012-13 and 2013-14 seasons

\begin{tabular}{|c|c|c|c|c|c|c|c|c|c|c|}
\hline & \multicolumn{5}{|c|}{$2012-13$} & \multicolumn{5}{|c|}{ 2013-14 } \\
\hline & $\mathrm{UZ}$ & DTC & Madziva & $\mathrm{H} /$ ford & Zimuto & $\mathrm{UZ}$ & DTC & Madziva & $\mathrm{H} /$ ford & Zimuto \\
\hline SC533 & 3947 & 4176 & 1610 & 3495 & 682 & 3127 & 2729 & 702 & 5056 & 2089 \\
\hline Pristine601 & 3407 & 4021 & 1413 & 3961 & 511 & 4158 & 3192 & 599 & 5238 & 3021 \\
\hline Pannar53 & 3283 & 2125 & 1336 & 3484 & 663 & 3353 & 3893 & 592 & 4785 & 2213 \\
\hline Pannar413 & 2374 & 2153 & 1408 & 3318 & 835 & 2301 & 2063 & 429 & 5475 & 2266 \\
\hline ZM309 & 2449 & 2037 & 799 & 1811 & 414 & 3469 & 2134 & 376 & 4351 & 1474 \\
\hline Zap51 & 2760 & 4030 & 937 & 3215 & 611 & 2668 & 2197 & 682 & 4434 & 1258 \\
\hline Zap61 & 2991 & 2730 & 1299 & 4053 & 672 & 3190 & 2874 & 729 & 4777 & 1463 \\
\hline PHB3253 & 2785 & 2912 & 1025 & 3518 & 595 & 3215 & 2831 & 248 & 5212 & 3364 \\
\hline ZM525 & 3614 & 2619 & 1213 & 3233 & 842 & 3860 & 2687 & 349 & 4898 & 2004 \\
\hline ZM401 & 3237 & 2517 & 1343 & 2677 & 737 & 3444 & 3397 & 798 & 4678 & 2451 \\
\hline PGS 63 & 3160 & 4282 & 1360 & 4817 & 640 & 4906 & 4826 & 559 & 5526 & 2970 \\
\hline SC637 & 3896 & 2649 & 2056 & 3390 & 654 & 3192 & 3232 & 673 & 4981 & 1953 \\
\hline ZS265 & 2982 & 3564 & 1625 & 3053 & 438 & 3732 & 5169 & 596 & 5285 & 3137 \\
\hline SC301 & 2921 & 2606 & 1120 & 3152 & 468 & 3378 & 2253 & 815 & 5609 & 1766 \\
\hline SC513 & 2835 & 4019 & 1553 & 2925 & 447 & 3657 & 1897 & 568 & 5172 & 2005 \\
\hline ZS261 & 3378 & 2354 & 915 & 3636 & 884 & 2776 & 3020 & 250 & 3513 & 1527 \\
\hline CA mean & $3126 a$ & $3050 a$ & $1313 b$ & 3359a & $631 a$ & $3402 a$ & $3025 b$ & $560 a$ & $4937 a$ & $2185 a$ \\
\hline SC533 & 2948 & 2265 & 1733 & 4781 & 1075 & 3693 & 3745 & 570 & 4425 & 1973 \\
\hline Pristine601 & 3845 & 2694 & 2273 & 3659 & 923 & 3995 & 4414 & 664 & 4097 & 3353 \\
\hline Pannar53 & 4471 & 2858 & 1748 & 2825 & 850 & 3191 & 4567 & 596 & 4524 & 2475 \\
\hline Pannar413 & 3382 & 2461 & 1941 & 3923 & 716 & 2979 & 2040 & 265 & 4287 & 2582 \\
\hline ZM309 & 3170 & 2307 & 2108 & 4419 & 641 & 3448 & 3251 & 759 & 3173 & 2005 \\
\hline Zap51 & 3709 & 2112 & 1409 & 3085 & 889 & 2900 & 2848 & 558 & 3256 & 1551 \\
\hline Zap61 & 4431 & 3173 & 1271 & 1782 & 586 & 3269 & 4641 & 314 & 5229 & 2094 \\
\hline PHB3253 & 3408 & 2576 & 1534 & 3982 & 1056 & 3116 & 2323 & 495 & 4663 & 2335 \\
\hline
\end{tabular}


Table 4. Continued

\begin{tabular}{|c|c|c|c|c|c|c|c|c|c|c|}
\hline & \multicolumn{5}{|c|}{$2012-13$} & \multicolumn{5}{|c|}{$2013-14$} \\
\hline & $\mathrm{UZ}$ & DTC & Madziva & $\mathrm{H} /$ ford & Zimuto & UZ & DTC & Madziva & $\mathrm{H} /$ ford & Zimuto \\
\hline ZM525 & 3680 & 2335 & 1610 & 4163 & 1009 & 3825 & 3054 & 573 & 3975 & 3024 \\
\hline ZM401 & 3488 & 2260 & 1580 & 4459 & 989 & 3618 & 3523 & 323 & 4223 & 2999 \\
\hline PGS 63 & 2741 & 3011 & 2144 & 4167 & 892 & 3633 & 5104 & 730 & 4467 & 4192 \\
\hline SC637 & 3668 & 3233 & 2145 & 3424 & 998 & 3102 & 4885 & 801 & 4176 & 2887 \\
\hline ZS265 & 2769 & 2652 & 1369 & 4012 & 969 & 4106 & 5012 & 549 & 4803 & 3290 \\
\hline SC301 & 3147 & 2740 & 1880 & 3873 & 557 & 3531 & 3211 & 770 & 4770 & 2194 \\
\hline SC513 & 3418 & 2756 & 1427 & 2476 & 883 & 3650 & 3723 & 608 & 3794 & 2448 \\
\hline ZS261 & 2708 & 3063 & 2054 & 3570 & 547 & 3092 & 3375 & 575 & 4528 & 1763 \\
\hline CP mean & $3436 a$ & $2656 b$ & $1764 a$ & $3663 a$ & $849 a$ & $3447 a$ & 3732a & $572 a$ & $4274 b$ & 2573a \\
\hline Trial mean & 3281 & 2665 & 1539 & 3511 & 740 & 3424 & 3378 & 566 & 4606 & 2379 \\
\hline Site mean & $4993 b$ & $4355 c$ & $1822 \mathrm{e}$ & $5813 \mathrm{a}$ & $1929 d$ & & & & & \\
\hline Year mean & $2347 b$ & & & & & $2871 \mathrm{a}$ & & & & \\
\hline SE & 720.1 & & & & & & & & & \\
\hline
\end{tabular}

Table 5. Accumulated analysis of variance output for grain yield $\left(\mathrm{kg} \mathrm{ha}^{-1}\right)$ under conservation agriculture (CA) and conventional practices (CP) at all experimental sites in both seasons.

\begin{tabular}{llllll}
\hline Source & DF & Sum of squares & Mean of square & Variance & P value \\
\hline Season & 1 & 85243969 & 85243969 & 72.09 & $<0.001$ \\
Site & 4 & 1332132265 & 333033066 & 281.63 & $<0.001$ \\
System & 1 & 4229524 & 4229524 & 3.58 & 0.059 \\
Treatment/maize variety & 15 & 79650665 & 5310044 & 4.49 & $<0.001$ \\
Season*Site & 4 & 144592773 & 36148193 & 30.57 & $<0.001$ \\
Season*System & 1 & 673042 & 673042 & 0.57 & 0.045 \\
Site*System & 4 & 18689359 & 4672340 & 3.95 & 0.004 \\
Season*Treat & 15 & 24820744 & 1654716 & 1.4 & 0.141 \\
Site*Treat & 60 & 84151999 & 1402533 & 1.19 & 0.166 \\
System*Treat & 15 & 28174934 & 1878329 & 1.59 & 0.071 \\
Season*Site*System & 4 & 8445811 & 2111453 & 1.79 & 0.13 \\
Season*Site*Treat & 60 & 93285015 & 1554750 & 1.31 & 0.061 \\
Season*System*Treat & 15 & 15869216 & 1057948 & 0.89 & 0.57 \\
Site*System*Treat & 60 & 59908449 & 998474 & 0.84 & 0.792 \\
Residual & 700 & 827768207 & 1182526 & & \\
Total & 959 & 2807635972 & 2927670 & & \\
\hline
\end{tabular}

Note. Season (2012-13 and 2013-14), Site (UZ (University of Zimbabwe), DTC (Domboshawa Training Center), Madziva, Hereford, Zimuto), System (CA and CP), Treatments (maize varieties).

\section{Discussion}

\subsection{Emergence under $C A$ and $C P$}

Higher emergence under CA compared with CP was found at DTC. This concurred results by Altuntaş \& Dede (2009) who reported high emergence rates under CA compared to CP in clay loamy soils. In their study, favorable soil physical properties for maize seedling emergence, which include lower bulk density, were found under CA compared to CP (Altuntas \& Dede, 2009). During our study high soil erosion was observed in the CP treatments at DTC because of the heavy rains received during emergence although erosion rates were not measured. This resulted in poor maize crop emergence under CP compared with the CA system. However, CP outperformed CA at UZ, Hereford and Zimuto. This is in line with observations made by Hayhoe et al. (1996), Griffith, Kladivko, Mannering, West, and Parsons (1988) and Dam et al. (2005) which were mainly attributed to low soil temperatures under CA systems compared with CP. Duiker et al. (2006) reported a delayed and uneven 
emergence under CA, but this delay did not affect vegetative growth or the final crop yield. Hillel (1998) pointed out that soil with more moisture, a scenario under CA compared to CP, heats up more slowly than a dry exposed soil, and this might explain the low temperature that potentially affected emergence. Moreover, since clay soil has ability to conserve more moisture than sandy soils, heating up of a mulched clay soil is even slower than an exposed bare clay soil. This could have affected emergence under CA compared to CP at UZ and Hereford in 2013-14. Zimuto experienced poor maize emergence under CA in both seasons and this could be attributed to delayed weeding and the little rains received at the time of planting. This could have led to a competition for the available moisture between the emerging maize seedlings and the weeds. Delayed weeding was as a result of the unsuitability of chemical weed control particularly glyphosate under very sandy soils due to its slow degradation nature (Locke et al., 2008). Hence manual weeding competed for labor with the seeding operations at the start of the cropping season. This shows that the success of CA also relies on the management practices being followed by farmers and the type of soils (Giller, Witter, Corbeels, \& Tittonell, 2009). These inconsistent results indicate the need to further investigate the effect of CA on crop emergence under different soil types. Furthermore, the effects of planting methods under CA must be explored. However, planting basins and direct seeding have shown high emergence percentage compared to ripping in difference parts of southern Africa (Ngwira, Thierfelder, \& Lambert, 2012b; Thierfelder \& Wall, 2009).

\subsection{Maize Early Vigour under $C A$ and $C P$}

Conservation agriculture has shown the potential to improve soil physical and chemical properties (Altundus \& Dede, 2009). This has the potential of increasing crop vigour through an improved nutrient cycling. Although plant vigour is determined by the genetics of a plant species, the environment plays a vital role in the exhibition of plant vigour (Negi, Baskheti, \& Bhatt, 2015). Furthermore, an improved emergence gives a better chance of high crop vigour. However, high emergence does not always translate into high plant vigour and final yield (Negi et al., 2015). Vigorous plants are associated with resistance to diseases and pests, and good root development which potentially translate to higher yield (Namuco, Cairns, \& Johnson, 2009). Lower dry matter and fewer leaves were generally found under CA compared with $\mathrm{CP}$ at the experimental sites during the two seasons. Furthermore lower dry matter and fewer leaves were observed under CA in light textured soils compared with heavy textured soils. This is because light textured soils have lower soil fertility and nutrient supply to growing plants is therefore limited compared to heavy textured soils (Chikowo et al., 2010). In addition, the soil chemical and physical analysis in this study revealed a high nutrient base in Hereford, DTC and UZ compared to Zimuto and Madziva. Moreover, at the light textured soil sites, soils from the CA treatment had less available $\mathrm{N}$ compared to CP plots. However, CA treatments at all sites had more total N compared with CP. Hence crops with access to high nutrient supply have better chances of having high vigour. The number of leaves per plant and in-vivo leaf chlorophyll at 6 weeks after sowing were higher under CP compared with CA. Verhulst et al. (2011a) found a slow initial growth in maize under CA compared with $\mathrm{CP}$. This relates to the availability of nutrients especially $\mathrm{N}$ during the early stages of crop growth. High $\mathrm{C}: \mathrm{N}$ ratio in residue types such as maize stover used in this study potentially caused immobilization of $\mathrm{N}$ making its uptake by plants slow (Chikowo et al., 2008). However, at DTC and Hereford more leaves and higher dry matter were found under CA compared with CP.

\subsection{Leaf Chlorophyll Trends through the Seasons under CA and CP}

High chlorophyll concentration early in the season is a very vital component in a plant's life. It shows how vigorous a crop is performing, and, although it is not the only indicator, gives an indication of the potential yield (Namuco et al., 2009). The chlorophyll content determines the level of photosynthesis and productivity (Egli \& Rucker, 2012). Lower chlorophyll content under CA can be explained by a number of reasons, but besides lower temperatures under CA it is mainly due to nitrogen lock-up (Mapfumo et al., 2007; Rasmussen, 1999). Low chlorophyll content in maize leaves under CA has also been observed where different residues are used as soil cover on light textured soil (Mupangwa, Nyagumbo, \& Mutsamba, 2016). Carbon and N turnover was found to be 1.5 times slower under CA than CP (Chivenge, Murwira, Giller, \& Mapfumo, 2007), which can explain the differences of chlorophyll content between the two systems. Moreover, the extend of differences also depend on clay content of the soil (Chivenge, 2003).

\subsection{Grain Yield under $C A$ and $C P$}

Generally there was no significant difference in yield between CA and CP over the sites and seasons. However, higher grain yield was observed under CA compared with CP at DTC in 2012-13 and Hereford in 2013-14. Even though Verhulst et al. (2011b) ascertained a slower growth under CA compared with CP which matches results of current study, this did not translate to yield differences under the two tillage systems. Although some differences were found in the maize growth patterns during the season between CA and CP such as emergence, chlorophyll 
and some early vigour parameters, this did not translate into yield differences at some sites. However, if these differences are addressed such as poor emergence, lower chlorophyll content at early stages and low vigour, and the potential persistence of foliar diseases under CA systems, yield is highly likely to increase. This study also suggests the need to identify sites which best suits the CA practice. In some sites in this study such as Zimuto, practicing CA showed no yield benefit compared with CP. However, Thierfelder and Wall (2009) found that CA in Zimuto increased yield both on maize and cowpea compared with CP although adoption remained poor. Furthermore, according to this work it is not all seasons that CA results in good yields or CP result in bad yields. Besides, yield performances under CA, other benefits must however, be considered such as reduced erosion and energy use, improvement of soil biological, chemical and physical properties which will bring benefits in the long term (Baudron, Thierfelder, Nyagumbo, \& Gérard, 2015).

\section{Conclusion}

The performance of maize varieties was tested on different soil types and rainfall regimes under two cropping systems (CA and CP) at five locations of Zimbabwe. Based on the results of this study the following conclusions can be made: there is a delay in nutrient accessibility by plants under CA which might be due to the nitrogen immobilization effect of residue mulch in CA systems. This highlights the need for a different fertilization strategy in terms of timing and formulations under CA systems. Chlorophyll content and early vigour characteristics were different under the two cropping systems which indicate the need to select maize varieties that are nutrient-efficient and suitable under CA systems. The study showed that maize yields are affected by a number of traits which emergence and chlorophyll content alone cannot explain. Breeding programs need to select for highly $\mathrm{N}$ use efficient varieties to suit CA. Although all the measured establishment and growth parameters showed differences under CA and CP, no grain yield differences were observed at some sites suggesting that if problems under $\mathrm{CA}$ such as $\mathrm{N}$ lock up are addressed, increases in crop yield are expected. Higher maize yield under CA compared with CP were observed at DTC and Hereford suggesting the site selective effects of CA practices. However, there is need for further investigations as the results of the present study are based on short-term data.

\section{Acknkowledgements}

This work was financially supported by the MAIZE Consultative Group on International Agriculture Research (CGIAR) research program and by the work of numerous farmers, field extension officers and researchers in Zimbabwe. Their contribution is gratefully acknowledged. Special thanks to Sign Phiri and Herbert Chipara for logistical and technical support during the course of this work.

\section{References}

Altuntaş, E., \& Dede, S. (2009). Emergence of silage maize as affected by conservational tillage, ridge and direct planting systems. Agricultural Engineering International: CIGR Journal.

Barbera, V. I. T. O., Poma, I., Gristina, L., Novara, A., \& Egli, M. (2012). Long-term cropping systems and tillage management effects on soil organic carbon stock and steady state level of $\mathrm{C}$ sequestration rates in a semiarid environment. Land Degradation \& Development, 23(1), 82-91. http://dx.doi.org/10.1002/1dr.1055

Baudron, F., Thierfelder, C., Nyagumbo, I., \& Gérard, B. (2015). Where to target conservation agriculture for African smallholders? How to overcome challenges associated with its implementation? Experience from Eastern and Southern Africa. Environments, 2, 338. http://dx.doi.org/10.3390/environments2030338

Burgess, M. S., Mehuys, G. R., \& Madramootoo, C. A. (1996). Tillage and crop residue effects on corn production in Quebec. Agronomy Journal, 88(5), 792-797. http://dx.doi.org/10.2134/agronj1996.000219 $62008800050017 x$

Cairns, J. E., Sanchez, C., Vargas, M., Ordoñez, R., \& Araus, J. L. (2012). Dissecting maize productivity: Ideotypes associated with grain yield under drought stress and well-watered conditions. Journal of Integrative Plant Biology, 54(12), 1007-1020. http://dx.doi.org/10.1111/j.1744-7909.2012.01156.x

Chikowo, R., Corbeels, M., Mapfumo, P., Tittonell, P., Vanlauwe, B., \& Giller, K. E. (2010). Nitrogen and phosphorus capture and recovery efficiencies and crop responses to arrange of soil fertility management strategies in sub-Saharan Africa. Nutrient Cycling in Agro ecosystems, 88(1), 59-77. http://dx.doi.org/ 10.1007/s10705-009-9303-6

Chikowo, R., Corbeels, M., Tittonell, P., Vanlauwe, B., Whitbread, A., \& Giller, K. E. (2008). Aggregating field-scale knowledge into farm-scale models of African smallholder systems: Summary functions to 
simulate crop production using APSIM. Agricultural Systems, 97(3), 151-166. http://dx.doi.org/10.1016/ j.agsy.2008.02.008

Chikowo, R., Mapfumo, P., Nyamugafata, P., Nyamadzawo, G., \& Giller, K. E. (2003). Nitrate-N dynamics following improved fallows and maize root development in a Zimbabwean sandy clay loam. Agroforestry Systems, 59(3), 187-195. http://dx.doi.org/10.1023/B:AGFO.0000005219.07409.a0

Chivenge, P. (2003). Tillage effects on soil organic matter fractions in long term maize trials in Zimbabwe (MPhil Thesis). University of Zimbabwe, Harare Zimbabwe.

Chivenge, P., Murwira, H., Giller, K., Mapfumo, P., \& Six, J. (2007). Long-term impact of reduced tillage and residue management on soil carbon stabilization: Implications for conservation agriculture on contrasting soils. Soil and Tillage Research, 94(2), 328-337. http://dx.doi.org/10.1016/j.still.2006.08.006

Dam, R. F., Mehdi, B. B., Burgess, M. S. E., Madramootoo, C. A., Mehuys, G. R., \& Callum, I. R. (2005). Soil bulk density and crop yield under eleven consecutive years of corn with different tillage and residue practices in a sandy loam soil in central Canada. Soil and Tillage Research, 84(1), 41-53. http://dx.doi.org/10.1016/j.still.2004.08.006

Derksen, D. A., Lafond, G. P., Thomas, G. A., Loeppky, H. A., \& Swanton, C. J. (1993). Impact of agronomic practices on weed communities: Tillage systems. Weed Sci., 41, 409-417.

Duiker, S. W., Haldeman J. F., \& Johnson, D. H. (2006). Tillage $\times$ maize hybrid interactions. Agronomy Journal, 98, 436-442. http://dx.doi.org/10.2134/agronj2005.0063

Egli, D. B., \& Rucker, M. (2012). Seed vigor and the uniformity of emergence of corn seedlings. Crop Science, 52(6), 2774-2782. http://dx.doi.org/10.2135/cropsci2012.01.0064

Giller, K. E., Witter, E., Corbeels, M., \& Tittonell, P. (2009). Conservation agriculture and smallholder farming in Africa: The heretics' view. Field Crops Research, 114(1), 23-34. http://dx.doi.org/10.1016/ j.fcr.2009.06.017

Govaerts, B., Verhulst, N., Castellanos-Navarrete, A., Sayre, K. D., Dixon, J., \& Dendooven, L. (2009). Conservation agriculture and soil carbon sequestration: between myth and farmer reality. Crit. Rev. Plant Sci., 28, 97-122. http://dx.doi.org/10.1080/07352680902776358

Griffith, D. R., Kladivko, E. J., Mannering, J. V., West, T. D., \& Parsons, S. D. (1988). Long-term tillage age and rotation effects on corn growth and yield on high and low organic matter, poorly drained soils. Agronomy Journal, 80(4), 599-605. http://dx.doi.org/10.2134/agronj1988.00021962008000040011x

Hayhoe, H., Dwyer, L., Stewart, D., White, R., \& Culley, J. (1996). Tillage, hybrid and thermal factors in corn establishment in cool soils. Soil and Tillage Research, 40(1), 39-54. http://dx.doi.org/10.1016/ S0167-1987(96)80005-5

Hillel, D. (1998). Environmental soil physics: Fundamentals, applications, and environmental considerations. Academic Press.

Kassie, G. T., Erenstein, O., Mwangi, W. M., La Rovere, R., Setimela, P., \& Langyintuo, A. (2012). Characterization of maize production in Southern Africa: Synthesis of CIMMYT/DTMA household level farming system surveys in Angola, Malawi, Mozambique, Zambia and Zimbabwe. Socio-Economics Program Working Paper 4, Mexico, D.F.: CIMMYT.

Locke, M. A., Zablotowicz, R. M., \& Reddy, K. N. (2008). Integrating soil conservation practice and glyphosate-resistant crops: Impacts on soil. Pest Management Science, 64(4), 457-469. http://dx.doi.org/ $10.1002 /$ ps. 1549

Lundy, M. E., Pittelkow, C. M., Linquist, B. A., Liang, X., Van Groenigen, K. J., Lee, J., \& Van Kessel, C. (2015). Nitrogen fertilization reduces yield declines following no-till adoption. Field Crops Research, 183, 204-210. http://dx.doi.org/10.1016/j.fcr.2015.07.023

Mapfumo, P., Mtambanengwe, F., \& Vanlauwe, B. (2007). Organic matter quality and management effects on enrichment of soil organic matter fractions in contrasting soils in Zimbabwe. Plant and Soil, 296, 137-150. http://dx.doi.org/10.1007/s11104-007-9304-7

Mhlanga, B., Cheesman, S., Maasdorp, B., Mupangwa, W., \& Thierfelder, C. (2015). Contribution of cover crops to the productivity of maize-based conservation agriculture systems in Zimbabwe. Crop Science, 55, 1791-1805. http://dx.doi.org/10.2135/cropsci2014.11.0796 
Mupangwa, W., Nyagumbo, I., \& Mutsamba, E. (2016). Effect of different mulching materials on maize growth and yield in conservation agriculture systems of sub-humid Zimbabwe. AIMS Agriculture and Food, 1(2), 239-253. http://dx.doi.org/10.3934/agrfood.2016.2.239

Mutema, M., Mafongoya, P. L., Nyagumbo, I., \& Chikukura, L. (2013). Effects of crop residue and reduced tillage on macro fauna abundance. Journal of Organic Systems, 1.

Namuco, O. S., Cairns, J. E., \& Johnson, D. E. (2009). Investigating early vigour in upland rice (Oryza sativa L.): Part I. Seedling growth and grain yield in competition with weeds. Field Crops Research, 113(3), $197-206$. http://dx.doi.org/10.1016/j.fcr.2009.05.008

Negi, M., Baskheti, D. C., \& Bhatt, S. S. (2015). Evaluation of seed germination and seedling vigour for single cross maize hybrids along with parental lines. Journal of Hill Agriculture, 6(2), 171-175. http://dx.doi.org/10.5958/2230-7338.2015.00038.5

Ngwira, A. R., Thierfelder, C., \& Lambert, D. M. (2012b). Conservation agriculture systems for Malawian smallholder farmers: Long-term effects on crop productivity, profitability and soil quality. Renewable Agriculture and Food Systems, First View, 1-14.

Nyamapfene, K. (1991). Soils of Zimbabwe (pp. 75-79). Nehanda Publishers (Pvt) Ltd, Harare, Zimbabwe.

Rasmussen, K. (1999). Impact of ploughless soil tillage on yield and soil quality: A Scandinavian review. Soil and Tillage Research, 53(1), 3-14. http://dx.doi.org/10.1016/S0167-1987(99)00072-0

Reicosky, D. C., Sauer, T. J., \& Hatfield, J. L. (2011). Challenging balance between productivity and environmental quality. Tillage impacts.

Thierfelder, C., \& Wall, P. C. (2012). Effects of conservation agriculture on soil quality and productivity in contrasting agro-ecological environments of Zimbabwe. Soil Use and Management, 28(2), 209-220. http://dx.doi.org/10.1111/j.1475-2743.2012.00406.x

Thierfelder, C., Cheesman, S., \& Rusinamhodzi, L. (2012). A comparative analysis of conservation agriculture systems: Benefits and challenges of rotations and intercropping in Zimbabwe. Field Crops Research, 137, 237-250. http://dx.doi.org/10.1016/j.fcr.2012.08.017

Thierfelder, C., Mutenje, M., Mujeyi, A., \& Mupangwa, W. (2014). Where is the limit? Lessons learned from long-term conservation agriculture research in Zimuto Communal Area, Zimbabwe. Food Security, 15-31.

Thierfelder, C., Rusinamhodzi, L., Ngwira, A. R., Mupangwa, W., Nyagumbo, I., Kassie, G. T., \& Cairns, J. E. (2014). Conservation agriculture in Southern Africa: Advances in knowledge. Renewable Agriculture and Food Systems, 1-21.

Thierfelder, C., \& Wall, P. C. (2009). Effects of conservation agriculture techniques on infiltration and soil water content in Zambia and Zimbabwe. Soil and Tillage Research, 105, 217-227. http://dx.doi.org/10.1016/ j.still.2009.07.007

Verhulst, N., Kienle, F., Sayre, K. D., Deckers, J., Raes, D., Limon-Ortega, A., ... Govaerts, B. (2011a). Soil quality as affected by tillage-residue management in wheat-maize irrigated bed planting system. Plant Soil, 340, 453-466. http://dx.doi.org/10.1007/s11104-010-0618-5

Verhulst, N., Nelissen, V., Jespers, N., Haven, H., Sayre, K., Raes, D., ... Govaerts, B. (2011b). Soil water content, maize yield and its stability as affected by tillage and crop residue management in rain fed semi-arid highlands. Plant and Soil, 344(1), 73-85. http://dx.doi.org/10.1007/s11104-011-0728-8

VSN International. (2002). GenStat for Windows (12th ed.). VSN International, Hemel Hempstead, UK. Retrieved from http://genstat.co.uk

Wortman, C., Shapiro, C., \& Tarkalson, D. (2006). Composting manure and other organic residues. University of Nebraska-Lincoln Extension, Institute of Agriculture and Natural Resources, Lincoln, Nebraska, USA.

\section{Copyrights}

Copyright for this article is retained by the author(s), with first publication rights granted to the journal.

This is an open-access article distributed under the terms and conditions of the Creative Commons Attribution license (http://creativecommons.org/licenses/by/4.0/). 